も関連があるように思われますが，ご意見をお聞かせ下さ $w_{0}$

（2）本論文で著者は心゙クトルのノルムに制約をかける ことによって，応答振幅が小さい部分での推定精度をよく していますが，計算に用いる応答関数に誤差が合まれると 仮定したモデルを考えることにより同様の効果が得ること は可能でしょうか。

【回答】（1）この研究の後に，(8)（9)式に任意係数 $a$, $b$ を掛けて計算を行ったことがあります。 $a, b$ の最適值を 系統的に探してはいないので詳しいことは言えませんが，
その結果では推定精度の向上が認められました。しかし， ABIC が複数の極値を持つ傾向は残っていたように記憶し ています。

（2）本研究では, 応答関数は理論計算 (ストリップ法) によって求められており，当然のことながら誤美が含まれ ていると思われます。したがって，応答関数自体にも誤差 が含まれると仮定するモデルは推定精度の向上に対して大 変有効ではないかと思われます。今後, 是非検討してみた いと思います。

\title{
12 航走する船船が遭遇する方向波スペクトルの推定法について
}

【討論】井関俊夫君（10)式のパラメトリックモデル において $a_{0}$ を Range- I， II，IIIで共通にしている理由を 教えて下さい。(15)式の $S\left(f_{e}\right)$ と $S(f)$ の関係式において, Range-I とRange-II の場合の分母は同じになりますが, Range-IIIの場合は他の 2 つの分母とは異なった值となり ます。したがって，絶対周波数べースにおいて $a_{0}$ が共通で あると考えると, 出会い周波数べースの(10)式に扔いては

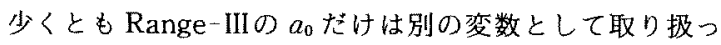
た方が良いように思えるのですがいかがでしょうか。

【回答】本推定法において， $a_{0}$ がどのような役割をしてい るか説明すれば，先生の討論に対する答になるかと思いま すので，簡単のため，波高計アレイの場合を例にとつて説 明したいと思います。波高計アレイの場台，パワーに関す る項 $\phi_{m m}\left(f_{e}\right)$ につて, (8) 式で $H_{m}^{*}\left(f_{e}, \alpha\right) H_{m}\left(f_{e}, \alpha\right)=1$ と することによって, 次の(1)式を得ます。

$$
\begin{aligned}
\phi_{m m}\left(f_{e}\right)= & \int_{-\pi}^{\pi}\left\{S^{\mathrm{l}}\left(f_{e}, x\right)+S^{11}\left(f_{e}, \chi\right)\right. \\
& \left.+S^{\prime \prime \prime}\left(f_{e}, x\right)\right\} d x
\end{aligned}
$$

(1)式に，本文(10)式を代入すれば，次の上うに表記で
きます。

$$
\begin{aligned}
\phi_{m m}\left(f_{e}\right)= & \exp \left(a_{0}\right) \int_{-\pi}^{\pi}\left[\operatorname { e x p } \left\{\sum _ { m = 1 } ^ { N } \left(a_{n}^{\mathrm{I}} \cos (n x)\right.\right.\right. \\
& \left.+b_{n}^{\mathrm{l}} \sin (n x)\right\} \\
& +\exp \left\{\sum_{m=1}^{N}\left(a_{n}^{\mathrm{II}} \cos (n x)+b_{n}^{\mathrm{II}} \sin (n x)\right\}\right. \\
& +\exp \left\{\sum_{m=1}^{N}\left(a_{n}^{\mathrm{III}} \cos (n x)+b_{n}^{\mathrm{III}} \sin (n x)\right\}\right] d x
\end{aligned}
$$

（1）式と（2）式を対比させて顶けたら分かりますよう に, 本推定法において， $a_{0}$ は本文 $(8)$ 式の Range- I, II, IIIのパラメトリックモデルの出合角に対するエネルギー分 布を示項 ((2)式の被積分項) から推定されるパワーを (1)を満足させるように調整するためのパラメータの役割 を果たしております。もらろん，ここで採用したパラメト リックモデルが最適で西るとは限りません。いろいるモデ ルが考えられるはずでありますし，先生のご指摘されたモ デルも一つの可能なモデルであると思います。

\section{9 半潜水式海洋構造物の水平部材に働く波力に及ぼす 3 次元影響}

【討論】水谷法美君 海洋構造物に作用する波力に及 沽す構造物の三次元性の効果を簡便に, しかも精度よく評 価できる手法を提示されており，その意義は大きいと思い ます。ただ，これらの評価式の娈当性について，実測流速 で評価した循環の值を使って行われていますので，計算結 果は流速の計測点（構造物表面からの距離）に依存するよ うに思いますが,この点に関してはどのように扔考えでし ょうか。

【回答】循環の強さを実測流速で算定する今回の方法で
は，流速の計測点によって循環の值が異なることになりま す。ここで用いている算出方法は，以下の上うな考え方に 基づいています。

本来，循環の値を算定するためには，ロワーハルの表面 に沿って流速を計测し，それらを皘分するという万法をと る必要がありますが，本実験装置ては上面の流速しか計湘 することができません。また，ロワーハルの断面は偏平な 矩形てあること, Fig. 20 で示立ように各角で虽離瀜が発生 することなどから，単純に柱体中心に渦系を置いただけで 